\title{
Authoritative school climate and peer victimization among Brazilian students
}

\author{
Hellen Tsuruda Amaral ${ }^{1}$ \\ Josafá Moreira da Cunha $\oplus^{1}$ \\ Jonathan Bruce Santo $\circledast^{2}$ \\ ${ }^{1}$ Universidade Federal do Paraná, PR, Brasil \\ ${ }^{2}$ University of Nebraska at Omaha, Nebraska, Estados Unidos da América
}

\begin{abstract}
According to the Authoritative School Climate theory, a school environment perceived with high levels of support and disciplinary structure can be a protective factor against violence. Therefore, the current study aimed to understand how support and disciplinary structure affected peer victimization among Brazilian students. Participants were 420 students from Brazil, between 7 and 14 years old (mean=10.02; S.D. $=.91) ; 51.5 \%$ of the participants were boys. Measures were obtained from a self-report questionnaire with measures of victimization, authoritative school climate and sociodemographic data. Using multilevel modeling between individual and same-sex peer group analyses, $89.86 \%$ of the victimization variability was at the individual level. Results indicated a negative association between the student's perception of support and reports of victimization, but no gender differences as predictors of victimization. Younger students who reported lowers perceptions of support also could be more victimized.
\end{abstract}

Keywords: peer victimization, authoritative school climate, bullying.

\section{Clima escolar autoritativo e vitimização entre pares em estudantes brasileiros}

Resumo

De acordo com a teoria do Clima Escolar Autoritativo, ambientes escolares percebidos com altos níveis de suporte e estrutura disciplinar podem ser protetores contra a violência. Portanto, o objetivo desse estudo foi entender como o suporte e a estrutura disciplinar afetaram o relato da vitimização entre pares. Os participantes foram 420 estudantes, entre 7 e 14 anos (média=10,02; d.p. $=0,91) ; 51,5 \%$ dos participantes eram meninos. As medidas foram obtidas a partir de questionário de autorrelato sobre vitimização, clima escolar autoritativo e dados sociodemográficos. Usando o modelo multinível, 89,86\% da variação da vitimização foi no nível individual. Os resultados indicaram uma associação negativa entre a percepção de suporte pelo aluno e os relatos de vitimização, mas não foram encontradas diferenças entre gêneros como preditores de vitimização. Os alunos mais jovens, que relataram menor percepção de suporte, também apresentaram tendência maior para a vitimização.

Palavras-chave: vitimização entre pares, clima escolar autoritativo, bullying.

\section{Clima escolar autoritativo y vitimización entre pares en estudiantes brasileños}

Resumen

De acuerdo con la teoría del clima escolar autoritativo, los ambientes escolares percibidos con altos niveles de soporte y estructura disciplinaria pueden ser protectores contra la violencia. El objetivo de este estudio fue entender cómo el soporte y la estructura disciplinar afectaron el relato de la victimización entre pares. Los participantes fueron 420 estudiantes, entre 7 y 14 años (promedio $=10,02$; d.e. $=0,91$ ); El 51,5\% de los participantes eran niños. Medidas fueron obtenidas a partir del autorrelato sobre victimización, clima escolar autoritario y datos sociodemográficos. Con el modelo multinivel, el 89,86\% de la variación de la victimización fue a nivel individual. Resultados indican asociación negativa entre lo soporte y los relatos de victimización, pero no se encontraron diferencias entre géneros como predictores de victimización. Los alumnos más jóvenes que relataron menor percepción de soporte también tienden a ser más victimizados.

Palabras clave: victimización entre pares, clima escolar autoritativo, bullying. 


\section{Introduction}

The school context, alongside families, is one the main environmental influences on children and adolescents. In this context, the quality of the relations between students, teachers and all the academic community plays a relevant role, being linked to outcomes such as school engagement (Cornell, Shukla, \& Konold, 2016), better academic performance (Gage, Prykanowski, \& Larson, 2014), among other indicators of positive development (Cornell \& Huang, 2016). However, those interactions can also lead to negative outcomes, such as violent behaviors like peer victimization (Cornell, Gregory, Huang, \& Fan, 2013). Assessing protection factors for violence, enhance social interactions could be an alternative (Gregory, Cornell, Fan, Sheras, \& Shih, 2010).

Social interactions within schools have been researched under different perspectives and various levels. For example, it has been established that teacher-student relations could be linked to the levels of violence and bullying in schools; according to the quality of this relations (Lamas, Freitas, \& Barbosa, 2013). In this sense, teachers that are perceived by their students as emotionally close and trustworthy could be more effective in school contexts and help reduce school violence (Wentzel \& Wigfield, 2009). Good relations between educators and students are also related to fewer reports of emotional problems such as depression and less reports of aggression in the school environment (Wang, Brinkworth, \& Eccles, 2013).

The School Climate also appears as an approach for understanding school environments and relationships. This concept has been investigated by many researchers and has different definitions. In general, school climate reflects the person's perception of the whole school context, besides only teacher-student interactions. Nevertheless, it is related to the quality of social interactions - between teachers, students, parents, principals, and others - and the school's structure, justice, rules, etc. (Bear et al., 2016).

In Brazil, the study of school climate and its impacts on student's adjustment has increased in recent years (Oliveira et al, 2013), and despite the absence of a universal definition for this construct (Thapa, Cohen, Guffey, \& Higgins-D’Alessandro, 2013), fairer environments has been indicated among the main aspects of a positive school climate in Brazilian schools, like presented in the study by Vinha and collaborators (2016).

In this paper the Authoritative School Climate framework is employed. According to this construct, the school climate can be understood by two main dimensions: disciplinary structure and student support (Gregory \& Cornell, 2009; Gregory, Cornell, Fan, Sheras, Shih, \& Huang, 2010). The disciplinary structure refers to how school rules are perceived to be rigid, but applied fairly (Gerlinger \& Wo, 2016). In turn, student support is related to their experience with teachers and other school professionals; perceived as welcoming, inclined to help and respectful (Huang et al., 2015).

An authoritative context is related to high scores in these two dimensions (Bear, Yang, Mantz, Hearn, \& Boyer, 2016). It is considered that the promotion of an authoritative school climate can help reduce the aggression situations by providing a less stressful and discordant environment, wherein students feel safe, serving as a protective factor against school violence (Cornell \& Huang, 2016). Also, the relation between those concepts are bidirectional and dynamic: environments with more aggression can also reflect lower perception on the authoritative school climate dimensions. In this way students will be encouraged to report situations in which they perceive a threat and thus facilitate timely interventions to solve these conflicts. According to this theory, this practice also provides alternatives so that the school does not need to use punishments and rigid responses to the student's inappropriate behaviors, which is beneficial since punishments and suspensions are related to school dropouts, disengagement and school failure (Cornell \& Huang, 2016).

An authoritative school climate has also been pointed out as a factor that can contribute to the promotion of better academic performance and social development. Another outcome reported is the reduction on peer victimization report (Cornell, Shukla, \& Konold, 2015).

\section{Peer victimization}

Peer victimization is one of the forms of aggression that may occur in the school environment. It is recurrent that the term "bullying" is used when school violence is cited, but violence, aggression and victimization are broader than this concept (Cunha, 2012). Bullying is characterized by an aggressive and harmful relation among peers, with an imbalance of power between the parties involved. In turn, bullying also involves such behaviors, but the emphasis is on intense repetition over a given period (Cunha, 2012).

In this form of interaction, aggression and/ or victimization behaviors may occur. Aggressive behaviors can be described as direct or indirect. Direct assaults usually involve physical action such as kicks, 
punches, shoving, or other manifestations. Relational aggressions usually involve aggressive behaviors whose function is to exclude and devalue the other, such as "ignoring" (Cunha, 2009). In this sense, victimization occurs when one of the parties suffers any of those behaviors. This relation is dynamic, and the same person can be the recipient of one or more of those behaviors, depending on the context (Cunha, 2009).

However, research indicates differences of involvement in peer victimization and bullying between genders, usually with more reports of physical aggression and victimization from boys and relational aggression and victimization from girls (Malecki et al., 2015; Stubbs-Richardson, Sinclair, Goldberg, Ellithorpe, \& Amadi, 2018).

Among the main consequences of peer victimization are: lower self-esteem, higher school dropout, low academic performance, higher rates of stress, and other negative outcomes (Cunha, 2009; Cornell et al., 2013). As such, it would be beneficial to develop research and behaviors towards a better school climate.

Unfortunately, peer victimization is a constant problem affecting Brazilian education. According to National School Health Survey (Pesquisa Nacional de Saúde Escolar) (IBGE, 2015), 19.8\% of Brazilian students reported having practiced bullying and $7.4 \%$ reported victimization. In this study, boys reported more aggressive behaviors than girls. Also, Brazilian teachers often do not feel able to deal with bullying and peer victimization (Silva, Oliveira, Bazon \& Cecilio, 2014). Thereby, it's still necessary to understand how the school climate in an authoritative approach is related to specific aspects of school social relations, such as involvement in peer victimization, especially in Brazilian schools.

Because it seems to be a negative association between an authoritative school environment and violent behaviors, and also gender differences into peer victimization involvement (Sentse, Kretschmer \& Salmivalli, 2015; Morelen, Southam-Gerowm \& Zeman, 2016); the purpose of this study was to assess how victimization in Brazilian schools was affected by the authoritative school climate dimensions - measured by support and disciplinary structure. Thereby, it was hypothesized that: (H1) at the individual level, victimization reports would be negatively related to the perception of both support and disciplinary structure; (H2) between-same-sex peer group level, boys were hypothesized to report higher levels of victimization when they reported lower scores of support and disciplinary structure; (H3) also, for younger students' same-sex peer groups, lower rates of support and disciplinary structure would impact in higher rates of victimization. Using multilevel modeling, support and disciplinary structure were tested at the individual level. Gender and age were tested at the between-samesex peer group level. The hypothesized analyses are presented in Figure 1.

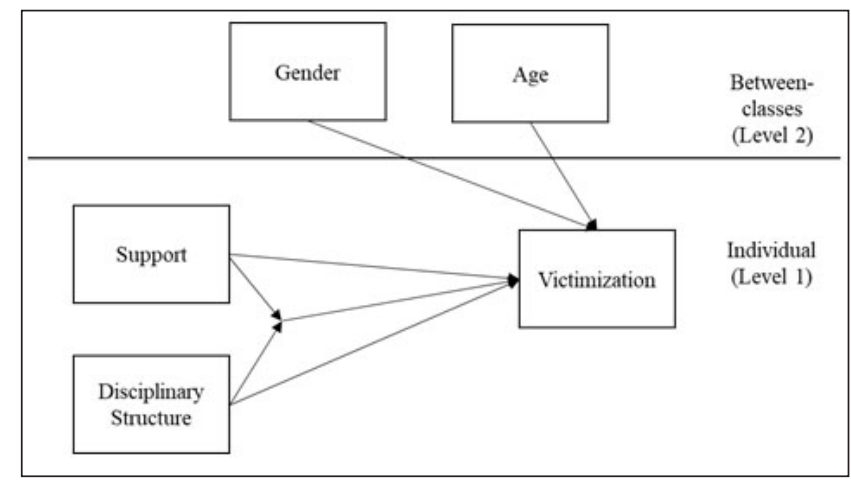

Figure 1. Conceptual map of the MLM analyses.

\section{Method}

\section{Participants}

Participants were 420 students from 19 classes of 11 different public elementary schools in the city of Curitiba, Brazil. The students were from third, fourth or fifth grade, range in age from 7 to 14 years old (mean=10.02; S.D. $=0.91$ ). In the sample $51.5 \%$ of the participants were boys and $48.5 \%$ girls; about their race/ethnicity, $52.4 \%$ were mixed-races, $36.4 \%$ were white; $5.6 \%$ black, $0.7 \%$ asian and $4.9 \%$ indigenous.

\section{Procedures}

This study is part of a larger investigation called "Peer victimization: individual and schools contexts factors" ("Vitimização entre Pares: fatores individuais e do contexto escolar"). The study was conducted after the approval from the Ethics Review Board (ERB) from the Federal University of Paraná (UFPR), alongside with the approval from the Curitiba Municipal Education Secretary. Each participant was only included in the research project following parent consent and individual assent. In the full study, 2436 students were invited to participate, and the participation rate was $80.0 \%$. For this article were analyzed only the data of the participants who answered the measures of school climate and of aggression-victimization (420 participants).

The researchers and assistants administered the questionnaires in one class at time; using electronic devices (tablets) with the Kobotoolbox app to collect the answers from the students (Harvard Humanitarian 
Initiative, n.d.). This app is an open-source tool for data collection developed by the United Nations Office for the Coordination of Humanitarian Affairs (OCHA), Harvard Humanitarian Initiative (HHI) and the International Rescue Committee (IRC). Data used in this analysis was collected in the last bimester (October-November) of the 2016 school year.

\section{Measures}

Measures were obtained through a self-report questionnaire including questions of personal/sociodemographic data and scales of peer victimization and authoritative school climate.

\section{Sociodemographics}

Each participant provided information about their age, gender (boys were coded as 0 and girls were coded as 1), school year (third, fourth or fifth grade) and race/ethnicity (black, white, mixed-races, indigenous or asian).

\section{Victimization}

Victimization was measured by the "Escala de Agressão e Vitimização" - Scale of Aggression and Victimization (SAV) (Cunha, Weber \& Steiner, 2009); This scale is a self-report instrument that measures peer aggression in school contexts (Cunha et al., 2009) and was validated in the Brazilian context. It can be applied to students in the second stage of elementary school and high school.

The full instrument consists of eighteen questions that comprise two larger dimensions: aggression (direct and relational) and victimization. Direct aggression involves items of direct practice of physical aggression, verbal and mixed forms (physical and verbal) in response to aggressions initiated by third parties. Relational aggression involves exclusion of peers in social relationships and other social situations that hinder the victim's relationship with third parties. Victimization was composed of the items in which the participant reports having suffered aggression (direct, relational and/or indirect physical). In the SAV, the items of each dimension are measured using a five-point Likert scale (1=never; $2=$ almost never; $3=$ =ometimes; 4=almost always; 5=always), which indicates the frequency of peer victimization in the last six months, such as "I was pushed, punched or kicked from colleagues"; "I threatened colleagues", etc.

In the validation study, Cronbach's alpha for direct aggression was .78; for relational aggression was .71 and for victimization was 0.81 (Cunha et al., 2009). Because of the purposes of this investigation, only items related to victimization were used in this study, Table 1 presents the Cronbach's alpha for victimization.

\section{Authoritative School Climate}

The Authoritative School Climate Rating Scale (EACEA) (Cornell \& Huang, 2016) is a self-report instrument composed by 15 items that investigates student perceptions of the school climate. Therefore, this instrument could be a fast alternative to evaluate the school climate. The scale was validated with students from the 6th year onwards and is composed of two dimensions: a) Support: This dimension refers to the student's perception of teachers and other adults in the school as welcoming, respectful and willing to help. Similarly, the conceptualization of this dimension can be equated with the concept of responsiveness indicated by Baumrind (1966) (Gerlinger \& Woo, 2016; Huang et al., 2015,); b) Disciplinary Structure: refers to how the school rules are perceived by the student. Perceived as fair, yet demanding or strict. This concept is close to the concept of "demandingness" in the model of parental styles proposed by Baumrind (1966) (Cornell, Shukla \& Konold, 2015; Huang et al., 2015).

In the original version of the instrument, the items in each subscale are measured by a four-point Likert scale, which indicates how much the student agrees with each statement ( $1=$ strongly disagree, $2=$ disagree, $3=$ agree, $4=$ I agree too much), such as "The punishment for breaking school rules is the same for all students.", "Most teachers and other adults at this school treat students with respect.", etc. The original scale Cronbach's Alpha was .76 for disciplinary structure and 0.73 for support (Cornell \& Huang, 2016). Because it is a recent instrument, the process of adaptation and validation for the Brazilian context is still in progress, but preliminary analysis have shown that the Cronbach's Alpha was .62 for disciplinary structure and 0.79 for support (Amaral, Macedo \& Cunha, no prelo). The Cronbach's alpha for disciplinary structure and support in this paper are described in Table 1.

\section{Statistical analysis}

A multilevel modeling approach was conducted on HLM software (version 6.04) to identify the variance accounted for each variable at the individual and same-sex peer group level. The Figure 1 represents the conceptual model of the analysis. To test for the individual variability, the outcome was victimization and the predictors were support, disciplinary structure and the interaction between these two variables. To test for the between-same-sex peer group variability, the predictors were age and gender differences. All 
between-individual variables were entered into the models as random.

\section{Results}

The Table 1 describes the means and standard deviations for the variables victimization, support and disciplinary structure. The Table 2 shows the correlations between the variables.

TABLE 1

Cronbach's Alpha, Means and Standard Deviations of Variables

\begin{tabular}{lccccc}
\hline & $\begin{array}{c}\text { Cronbach's } \\
\text { Alpha }\end{array}$ & $\begin{array}{c}\text { Number } \\
\text { of items }\end{array}$ & N & Mean & S.D. \\
\hline Victimization & .851 & 8 & 420 & 1.90 & .66 \\
Support & .840 & 8 & 420 & 3.26 & .61 \\
$\begin{array}{l}\text { Disciplinary } \\
\text { Structure }\end{array}$ & .636 & 7 & 420 & 2.97 & .59 \\
\hline
\end{tabular}

TABLE 2

Correlations Among Variables

\begin{tabular}{lcccc}
\hline & Victimization & Support & $\begin{array}{c}\text { Disciplinary } \\
\text { Structure }\end{array}$ & Gender \\
\hline 1. Victimization & - & - & - & - \\
2. Support & $-.188 * *$ & - & - & - \\
$\begin{array}{l}\text { 3. Disciplinary } \\
\quad \text { Structure }\end{array}$ & .029 & .026 & - & - \\
4. Age & .004 & .063 & $-.117 *$ & - \\
5. Gender & -.030 & $.100 *$ & .042 & -.007 \\
\hline$* p<.05 ; * * p<.01$. & & & &
\end{tabular}

\section{Unconditional model}

The intra-class correlation (ICC) from the unconditional model (model 00 ) revealed that 10.86\% of the variability in the peer victimization was betweensame-sex peer groups. So, $89.14 \%$ of the variability was at the individual level in this model. There was significant variability at the between-same-sex peer group level, $\chi_{(37)}^{2}=85.56, p<.05$.

\section{Individual level analyses}

The first variable to be entered the model (model 01) was support. There was a significant positive association with peer victimization; $b=-.17, \mathrm{SE}=.04$, $t(37)=-3.72, p=.001$. This variable reduced prediction error, $\mathrm{PRPE}=3.7 \%$, and significantly improved the model, $\Delta \chi_{(2)}^{2}=10.13$. The effect was set as random such that it was assumed to vary across same-sex peer groups.

In the second model, disciplinary structure was included as a predictor. There was no significant effect for disciplinary structure; $\mathrm{b}=-.01, \mathrm{SE}=.04, t(37)=.36$, $p=.718$. However, support remained a significant and negative predictor $b=-.17, \mathrm{SE}=.04, t(37)=-3.72$, $p=.001$. Disciplinary structure did not reduce prediction error nor improved the model, $\Delta \chi_{(5)}^{2}=2.12, p=.718$. Nevertheless, the effect was kept as random to test for differences across same-sex peer groups.

For model 03, the interaction between support and disciplinary structure was included as a predictor. There was not a significant effect for the interaction between support and disciplinary structure $b=-.04, \mathrm{SE}=.05$, $t(37)=-.91, p=.368$. At this point, only support was a significant and negative predictor of peer victimization; $\mathrm{b}=-.17, \mathrm{SE}=.05, t(37)=-3.27, p=.003$. In this model there was a reduction in prediction error, $\mathrm{PRPE}=2.0 \%$, but did not improve the model, $\Delta \chi_{(4)}^{2}=4.25, p=.368$. Lastly, this effect was also kept as random.

\section{Same-sex peer group analyses}

Because there was a significant variance in the victimization report among same-sex peer groups, the effects between them were estimated. Gender was the first variable entered into the between-same-sex peer group model (model 4). No significant effect was found for gender; $\mathrm{b}=-.04, \mathrm{SE}=.95, t(420)=-.73, p=.469$. Though, this effect accounted for a $18.24 \%$ reduction in the proportion of prediction error, it did not significantly improve the model, $\Delta \chi_{(1)}^{2}=.05, p>.500$. No significant effect was observed for disciplinary structure; $b=.00$, $\mathrm{SE}=.06, t(420)=.06, p=.953$. The addition of this variable did not reduce prediction error and did not significantly improve the model; $\Delta \chi_{(1)}^{2}=.31, p>.500$. No significant effect was observed for the interactions between support and disciplinary structure; $b=-.04, \mathrm{SE}=.05, t(420)=-.73$, $p>.500$. The addition of this interaction did not reduce prediction error and did not significantly improve the model; $\Delta \chi_{(1)}^{2}=.41, p>.500$. In model 5 , the variable age was entered into the between-same-sex peer group model. This effect did not reduce prediction error and did not significantly improve the model; $\Delta \chi_{(1)}^{2}=.02$, $p>$.500. Table 3 contains final model estimates.

TABLE 3

Final Multilevel Model of Individual and Same-Sex peer Group Predictors

\begin{tabular}{lccccc}
\hline Fixed Effect & $b$ & S.E. & $T$ & $d f$ & $P$ \\
\hline Intercept & .01 & .08 & .24 & 35 & .809 \\
Age & .04 & .11 & .34 & 35 & .736 \\
Gender & -.10 & .08 & -1.27 & 35 & .212 \\
Support & -.16 & .04 & -3.32 & 37 & .002 \\
Disciplinary Structure & .01 & .05 & .08 & 37 & .941 \\
$\begin{array}{l}\text { Interaction between support } \\
\text { and disciplinary structure }\end{array}$ & -.03 & .05 & -.71 & 37 & .480 \\
\hline
\end{tabular}




\section{Discussion}

The aim of the current study was to assess how the perception of support and disciplinary structure was associated with Brazilian students' reports of being victimized by their peers at school. In this sample, only support was a significant negative predictor for reports of victimization. This finding partially corroborates to those by Cornell and Huang (2016); because only one of the dimensions related to an authoritative school climate, was associated to lower rates of aggressive behavior in school environments.

The interaction between victimization and disciplinary structure was not significant neither at individual level and between-same-sex peer group level. This result may indicate that there are differences in the Brazilian context regarding this theory, at least in this sample. Some researchers point in Brazilian schools the existence of coercive or abusive rules, such as not allowing students to access the bathroom during class time (Vinha et al., 2016) and also the lack of dialogue with the students (Reis, 2012). A school environment with these characteristics may not be configured as a provider of disciplinary structure as proposed by the authoritative theory, nonetheless, it is necessary to expand research more for more reliable conclusions.

Among the other hypotheses, at the same-sex peer group level, no gender differences were found as predictors of the scores of victimization, contradictory to expected, given the relations between gender, school climate (Eliot, Cornell, Gregory \& Fan, 2010) and victimization report (Sentse et al., 2015; Morelen et al., 2016).

In order to test $\mathrm{H} 3$, adding age into the equation, divergences between the reports of victimization were found for support. The results indicate that younger students could be more victimized when their perception of support was lower. This finding is divergent from some studies in the area, like Cornell and Huang (2016) and Huang et al. (2015), previously cited.

The current study had some limitations. First, some of the assumptions for multilevel modeling were met, but some were not. For the dependent variable victimization, it was a quantitative predictor, had nonzero variance and had no perfect multicollinearity. Also, this variable was not normally distributed and as a result the distribution of the errors appear not to be normal either, had no perfect homoscedascity and no perfect linear association. However, was dependent on the other variables and the scatterplot showed a tendency of a linear relationship.

The only measure for the variables was the selfreport from the students. Maybe if there were other sources of data, such as reports from teachers or direct observation of the contexts, more information could be used for the analyses. Likewise, larger samples could improve the quality of the data as well. Future studies can use larger samples, more source of data and maybe do a longitudinal comparison. The attention for the assumptions of multilevel modeling is also a suggestion for next researches in the field.

Violence in schools is a complex and multilevel problem. However, good relations between all the persons of the school environment is a powerful tool against this issue. Therefore, the results of this study demonstrate that enhance levels of student support in Brazilian schools, above and beyond investing in rules in the school context, could be a protective factor against peer victimization. Given the results of this study and many before, it appears necessary that the school community research and provide ways to enhance the relations in schools. In order to develop authoritative school's environments seems necessary to combine individual efforts with the school community and public policies to promote the improvement of the school climate.

\section{References}

Amaral, H. T., Macedo, A. M. B., \& Cunha, J. M. (no prelo). Evidências de confiabilidade e validade da versão brasileira da Escala de Avaliação do Clima Escolar Autoritativo. Curitiba, PR: Universidade Federal do Paraná - UFPR. (DOI INEXISTENTE)

Baumrind, D. (1966). Effects of authoritative parental control on child behavior. Child development, 37 (4), pp. 887-907. doi:10.2307/1126611

Bear, G. G., Yang, C., Mantz, A. H. L., Hearn, S., \& Boyer, D. (2016). Technical Manual for the Delaware School Survey: Scales of School Climate; Bullying Victimization; Student Engagement; Positive, Punitive, and Social Emotional Learning Techniques; and Social and Emotional Competencies. Retrieved from http://wh1.oet.udel.edu/pbs/wpcontent/uploads/2011/12/Delaware-School-Survey-Technical-Manual-Fall-2016.pdf. (DOI INEXISTENTE)

Bear, G. G., Holst, B., Lisboa, C., Chen, D., Yang, C., \& Chen, F. F. (2016). A Brazilian Portuguese survey of school climate: Evidence of validity and reliability. International Journal of School \& Educational Psychology, 4(3), 165-178. doi:10.1080/21683603.2015.1094430 
Cornell, D., Gregory, A., Huang, F., \& Fan, X. (2013). Perceived prevalence of teasing and bullying predicts high school dropout rates. Journal of Educational Psychology, 105(1), 138. doi:10.1037/a0030416

Cornell, D. \& Huang, F. (2016). Authoritative school climate and high school student risk behavior: a cross-sectional multi-level analysis of student self-reports. Journal of Youth and Adolescence, 45(11), pp. 2246-2259. doi:10.1007/ s10964-016-0424-3

Cornell, D., Shukla, K., \& Konold, T. R. (2015). Peer victimization and authoritative school climate: A multilevel approach. Journal of Educational Psychology, 107(4), 1186-1201. doi:10.1037/edu0000038

Cornell, D., Shukla, K., \& Konold, T. R. (2016). Authoritative school climate and student academic engagement, grades, and aspirations in middle and high schools. AERA Open, 2(2), pp. 1-18. doi:10.1177/2332858416633184

Cunha, J. M. (2012). O papel moderador de docentes na associação entre violência escolar e ajustamento acadêmico (Doctoral dissertation). Retrieved from https://www.acervodigital.ufpr.br/bitstream/handle/1884/34643/R\%20-\%20 T\%20-\%20JOSAFA\%20MOREIRA\%20DA\%20CUNHA.pdf?sequence=1 (DOI INEXISTENTE)

Cunha, J. M., Weber, L. N. D., \& Steiner, P. (2009). Escala de vitimização e agressão entre pares (EVAP). In Weber, L. \& Dessen, M. A. (Ed.), Pesquisando a Família: Instrumentos Para Coleta e Análise de Dados (pp. 92-101). Curitiba, PR: Juruá. (DOI INEXISTENTE)

Eliot, M., Cornell, D., Gregory, A., \& Fan, X. (2010). Supportive school climate and student willingness to seek help for bullying and threats of violence. Journal of school psychology, 48(6), 533-553. doi:10.1016/j.jsp.2010.07.001

Gage, N. A.; Prykanowski, d. A.; Larson, A. (2014). School climate and bullying victimization: A latent class growth model analysis. School Psychology Quarterly, 29(3), 256-271. doi:10.1037/spq0000064

Gerlinger, J. \& Wo, J. C. (2016). Preventing School Bullying: Should Schools Prioritize an Authoritative School Discipline Approach Over Security Measures?. Journal of School Violence, 15(2), pp. 133-157. doi:10.1080/1538 8220.2014.956321

Gregory, A. \& Cornell, D. (2009). “Tolerating” adolescent needs: Moving beyond zero tolerance policies in high school. Theory into Practice, 48(2), 106-113. doi:10.1080/00405840902776327

Gregory, A., Cornell, D., Fan, X., Sheras, P., \& Shih, T. (2010). Authoritative school discipline: High school practices associated with lower student bullying and victimization. Journal of Educational Psychology, 102 (2), $483-496$. doi:10.1037/a0018562

Instituto Brasileiro de Geografia e Estatística (2015). Pesquisa Nacional de Saúde Escolar 2015 [National School Health Survey 2015]. Retrieved from https://biblioteca.ibge.gov.br/visualizacao/livros/liv97870.pdf. (DOI INEXISTENTE)

Harvard Humanitarian Initiative. (n.d.). Kobo Toolbox. Retrieved November 14, 2017, from http://www.kobotoolbox. org/. (DOI INEXISTENTE)

Huang, F. L., Cornell, D. G., Konold, T., Meyer, J. P., Lacey, A., Nekvasil, E. K., Heilbrun, A., \& Shukla, K. D. (2015). Multilevel Factor Structure and Concurrent Validity of the Teacher Version of the Authoritative School Climate Survey. Jounal of School Health, 85(12), 843-851. doi:10.1111/josh.12340

Lamas, K. C. A., Freitas, E. R., \& Barbosa, A. J. G. (2013). Bullying e relação professor-aluno: percepções de estudantes do ensino fundamental. Psico, 44(2), 263-272. (DOI INEXISTENTE)

Malecki, C. K., Demaray, M. K., Coyle, S., Geosling, R., Rueger, S. Y., \& Becker, L. D. (2015). Frequency, power differential, and intentionality and the relationship to anxiety, depression, and self-esteem for victims of bullying. Child \& Youth Care Forum, 44(1), pp. 115-131. doi:10.1007/s10566-014-9273-y

Morelen, D., Southam-Gerow, M., \& Zeman, J. (2016). Child emotion regulation and peer victimization: The moderating role of child sex. Journal of Child and Family Studies, 25(6), pp. 1941-1953. doi:10.1007/s10826-016-0360-6

Oliveira, R. P., Bauer, A., Ferreira, M. P., Minuci, E. G., Lisauskas, F., Carvalho, M. X., \& Caldeira, C. (2013). Análise das desigualdades intraescolares no Brasil. São Paulo, SP: Fundação Vitor Civita. doi:10.13140/RG.2.1.5081.7682

Reis, R. (2012). Experiência escolar de jovens/alunos do ensino médio: os sentidos atribuídos à escola e aos estudos. Educação e Pesquisa, 38(3), pp. 637-652. doi:10.1590/S1517-97022012000300007

Sentse, M., Kretschmer, T., \& Salmivalli, C. (2015). The longitudinal interplay between bullying, victimization, and social status: Age-related and gender differences. Social Development, 24(3), 659-677. doi:10.1111/sode.12115

Silva, J. L., Oliveira, W. A., Bazon, M. R., \& Cecilio, S. (2014). Bullying: Conhecimentos, Atitudes e Crenças de professores. Psico, 45(2), pp. 147-156. doi:10.15448/1980-8623.2014.2.12683

Stubbs-Richardson, M., Sinclair, H. C., Goldberg, R. M., Ellithorpe, C. N., \& Amadi, S. C. (2018). Reaching out versus lashing out: Examining gender differences in experiences with and responses to bullying in high school. American Journal of Criminal Justice, 43(1), 39-66. doi:10.1007/s12103-017-9408-4

Thapa, A., Cohen, J., Guffey, S., \& Higgins-D'Alessandro, A. (2013). A review of school climate research. Review of educational research, 83(3), 357-385. doi:10.3102/0034654313483907

Vinha, T. P., de Morais, A., Tognetta, L. R. P., Azzi, R. G., de Aragão, A. M. F., Marques, C. D. A. E., \& Oliveira, M. T. A. (2016). O clima escolar e a convivência respeitosa nas instituições educativas. Estudos em Avaliação Educacional, 27(64), 96-127. doi:10.18222/eae.v27i64.3747

Wang, M. T., Brinkworth, M., \& Eccles, J. (2013). Moderating effects of teacher-student relationship in adolescent trajectories of emotional and behavioral adjustment. Developmental psychology, 49(4), 690-705. doi:10.1037/ a0027916 
Wentzel, K., Wigfield, A., \& Miele, D. (2009). Handbook of motivation at school. New York, NY: Routledge. doi: $10.4324 / 9780203879498$

Dados dos autores:

Hellen Tsuruda Amaral - Mestra, Universidade Federal do Paraná.

Josafá Moreira da Cunha - Doutor, Universidade Federal do Paraná.

Jonathan Bruce Santo - Doutor, University of Nebraska at Omaha.

Endereço para correspondência:

Hellen Tsuruda Amaral

Rua Visconde de Guarapuava, 2763, apto. 81

80010-100, Curitiba, PR, Brasil

E-mail: hellentsuruda@gmail.com

Recebido em: 27/11/2017.

Aceito em: 31/08/2018.

Publicado em: 09/05/2019. 